\title{
Recovery of Trichostrongylus colubriformis infective larvae from three grass species contaminated in the autumn
}

\author{
Recuperação de larvas infectantes de Trichostrongylus colubriformis \\ em três espécies de gramíneas contaminadas no outono \\ Raquel Abdallah da Rocha ${ }^{1,2 *}$; Patrizia Ana Bricarello ${ }^{3}$; Gilberto Pedroso da Rocha ${ }^{4}$; \\ Alessandro Francisco Talamini do Amarante ${ }^{1}$
}

\begin{abstract}
${ }^{1}$ Departamento de Parasitologia, Instituto de Biociências, Universidade Estadual Paulista - UNESP, Botucatu, SP, Brasil
${ }^{2}$ Curso de Zootecnia, Faculdades Associadas de Uberaba - FAZU, Uberaba, MG, Brasil

${ }^{3}$ Departamento de Zootecnia e Desenvolvimento Rural, Centro de Ciências Agrárias, Universidade Federal de Santa Catarina - UFSC, Florianópolis, SC, Brasil

${ }^{4}$ Departamento de Produção Animal, Faculdade de Medicina Veterinária e Zootecnia, Universidade Estadual Paulista - UNESP,

Botucatu, SP, Brasil
\end{abstract}

Received March 5, 2012

Accepted September 13, 2012

\begin{abstract}
This experiment aimed to assess the recovery of infective larvae (L3) of Trichostrongylus colubriformis from Brachiaria decumbens cv. Australiana, Cynodon dactylon cv. Coast-cross and Panicum maximum cv. Aruana. The experimental module comprised six plots, with two plots per herbage species. Larval survival was assessed from autumn to winter, under the effect of two herbage-paring heights $(5$ and $30 \mathrm{~cm})$. TThe paring was carried out immediately before contamination with faces containing $T$. colubriformis eggs. The feces and herbage were collected at one, two, four, eight, 12 and 16 weeks after feces had been deposited in the experimental plots. In general, larvae were recovered from both herbage and feces until the $16^{\text {th }}$ week. The longer persistence of these larvae in the environment was probably due to warmer temperatures. The number of L3 recovered from the pasture was not influenced by the height of plants, except for Brachiaria and Aruana herbage in the fourth week. Regarding the concentrations of larvae per kg of dry matter (L3/kg DM), recovery was higher from low pasture in all three herbage species. During the autumn, the development and survival of the T. colubriformis free-living stages were not affected by the different herbage species.
\end{abstract}

Keywords: Herbages, sheep, epidemiology, Trichostrongylus colubriformis, nematodes.

\section{Resumo}

O experimento teve como objetivo avaliar a recuperação de larvas infectantes (L3) de Trichostrongylus colubriformis em Brachiaria decumbens cv. Australiana, Cynodon dactylon cv. Coast-cross e Panicum maximum cv. Aruana. Foram utilizados módulos experimentais constituídos por seis canteiros, perfazendo dois canteiros por espécie forrageira. A sobrevivência larval foi avaliada do outono até o inverno, sob o efeito de duas alturas de poda $(5$ e $30 \mathrm{~cm})$. A poda foi realizada imediatamente antes da deposição das fezes contaminadas com ovos de T. colubriformis. A colheita das fezes e da forragem foi realizada uma, duas, quatro, oito, 12 e 16 semanas após a deposiçáo das fezes nos canteiros experimentais. De modo geral, foram recuperadas larvas das forragens e das fezes até a $16^{a}$ semana. Essas larvas persistiram por mais tempo no ambiente, provavelmente em razão das temperaturas mais amenas. O número de $\mathrm{L} 3$ recuperadas nas pastagens não foi influenciado pela altura das plantas, exceto nos capins braquiária e aruana na quarta semana. Já em relação às concentraçóes de larvas (L3/kg MS) recuperadas das três forrageiras, houve maior concentração nas pastagens baixas. Durante o outono, o desenvolvimento e a sobrevivência de estádios de vida livre de T. colubriformis não foram afetados pelos diferentes tipos de espécies de forrageiras.

Palavras-chave: Forragens, ovinos, epidemiologia, Trichostrongylus colubriformis, nematódeos.

\footnotetext{
${ }^{*}$ Corresponding author: Raquel Abdallah da Rocha

Departamento de Parasitologia, Instituto de Biociências,

Universidade Estadual Paulista - UNESP, Botucatu, SP, Brasil

e-mail: rrabdallah@hotmail.com
} 


\section{Introduction}

Sheep breeding is an activity with vast production potential in terms of meat, wool, skin and milk. Lamb meat production, the main ability of the breeds raised in the State of Sao Paulo, Brazil, has aroused increasing interest in farmers who have attempted to structure the commercialization system (CARVALHO et al., 2004). As sheep breeding in Sao Paulo is mainly semi-intensive, it is essential that studies be carried out to indicate the management systems and ovine breeds with the highest potential for meat production under the environmental conditions of this State.

The anthelmintic resistance of most species involved in parasitic infections is a major problem for sheep breeding not only in Brazil (AMARANTE et al., 1992; ECHEVARRIA et al., 1996) but also in any other place where this activity is relevant (WALLER, 1997; BARTLEY et al., 2004, 2006). In the past two decades, this problem has led to further studies once it is a great threat to small ruminant production.

Thus, it is necessary to adopt new worm control practices, such as the use of herbage, to reduce the number of infective larvae (L3) in pasture, because of both the microclimate provided by herbages and the migration difficulties faced by larvae due to the morphology of each herbage species.

The development and survival of free-living stages are influenced by the climate. Survival time is highly variable in the different regions of Brazil, as well as through the different seasons of the year. The present study aimed to assess the following: the recovery of Trichostrongylus colubriformis L3 from three herbage species: Brachiaria decumbens cv. Australiana, Cynodon dactylon cv. Coast-cross and Panicum maximum cv. Aruana, contaminated at the beginning of the autumn; the influence of herbage height ( 5 and $30 \mathrm{~cm}$ ) at the moment of contamination; and the L3 survival in pasture during the autumn.

\section{Materials and Methods}

The experiment was carried out at the Sheep Breeding Area of UNESP - "Universidade Estadual Paulista", Botucatu Campus $\left(22^{\circ} 50^{\prime} \mathrm{S}\right.$ and $\left.48^{\circ} 24^{\prime} \mathrm{W}\right)$. Meteorological data were obtained from the Environmental Sciences Area of the Department of Natural Resources, School of Agronomical Sciences, UNESP, Botucatu Campus. Infective larvae of Trichostrongylus colubriformis were obtained and kept as described by Rocha et al. (2007).

\section{Experimental module}

Details about the experimental module were described by Rocha et al. (2008). The experimental module comprised six plots of $32.4 \mathrm{~m}^{2}$ each, established with $B$. decumbens cv. Australiana, C. dactylon cv. Coast-cross and P. maximum cv. Aruana, in a total of two plots per species.

Each plot was divided into 36 subplots of $30 \times 30 \mathrm{~cm}$, i.e. six replicates per species and per height at each sampling date. Nylon threads and wooden stakes were used to make such divisions. To prevent a herbage species from invading the area of another species, the spaces between plots were periodically cleaned.
Larval recovery was assessed under the effect of two herbage-paring heights (low, $5 \mathrm{~cm}$ and high, $30 \mathrm{~cm}$ ). The paring was carried out immediately before the deposition of feces; appropriate scissors were used to prevent sectioned parts from falling on the ground.

\section{Deposition offeces}

On the day feces were deposited, five counts of eggs per gram of feces (EPG) were performed to estimate the total number of T. colubriformis eggs present in the samples. A total of 221 samples were prepared and each one contained 15 grams of feces. Details about coproculture and fecal deposition were described by Rocha et al. (2008). Of the 221 samples, 216 were deposited on the plots and the remaining five were destined to coproculture in Petri dishes (control group). The samples were deposited on the plots between 12:00 PM and 1:00 PM on May 07, 2004. Fecal samples were deposited directly on the soil and were not protected against the action of insects or other predators.

\section{L3 recovery from herbage and fecal samples}

The feces and herbage were collected at one, two, four, eight, 12 and 16 weeks after feces had been deposited on the experimental plots. At every week, samples were collected from six plots per herbage species and height. All collections were performed between 6:30 AM and 7:30 AM. Details about L3 recovery from herbage and fecal samples were described by Rocha et al. (2008).

Herbage samples were stored in buckets, separately. They were kept immersed in four liters of water for four hours. After that, each herbage sample was transferred to another bucket containing four liters of water, remaining immersed for further three hours, thus totaling seven hours of herbage sample immersion in water (NIEZEN et al., 1998).

After seven hours, the herbage samples were removed, packed in paper bags and dried in oven for dry matter determination.

The water in the buckets remained at rest for 24 hours; then, the supernatant was removed and the sediment was transferred to a sedimentation cup. After a 24-hour additional sedimentation process, the supernatant was discarded and the sediment was transferred to a capped graduated conical tube. The tubes were kept in refrigerator $\left(4^{\circ} \mathrm{C}\right)$ until reading, when supernatant was again discarded and $1.0 \mathrm{~mL}$ sediment was examined to quantify T. colubriformis L3. Results were expressed as mean number of L3. In addition, the mean concentration of L3 on the herbage, i.e. the mean number of L3 per kilogram of dry matter (L3/kg DM) was estimated.

The feces that remained on the plots were collected and stored in labeled plastic bags until processing in laboratory. The larvae were separated from the feces as previously described by Rocha et al. (2008).

The rate of larval recovery from the environment was calculated based on the number of infective larvae obtained from feces deposited on the plots, relative to the number of infective larvae produced in the fecal cultures kept in the laboratory (control). The following formula was employed: 
Recovery rate $=100^{*}$ (mean number of L3 recovered from feces deposited in the environment/mean number of L3 in the cultures of the control group).

\section{Statistical analysis}

Data were subjected to one-way analysis of variance, using the software Minitab (version 11, 1996). Means were compared by the Tukey's test with $5 \%$ significance level. The data on infective larvae were previously transformed $(\log (x+1))$. However, the arithmetic means of non-transformed data are presented to make results clearer.

\section{Results}

Rainfall in the study period was $213.7 \mathrm{~mm}$ and the average maximal and minimal temperatures were $22.0{ }^{\circ} \mathrm{C}$ and $13.0{ }^{\circ} \mathrm{C}$, respectively. Fecal samples showed, on average, 475 EPG. The mean number of larvae recovered from the cultures for the control group was $2960 \mathrm{~L} 3$, which corresponded to an egg-to-larva development rate of $41.5 \%$.

The mean temperature on the day feces were deposited (May 2004 ) was $16.8^{\circ} \mathrm{C}$. Although it did not rain on that day, the air relative humidity was $82 \%$. Data about the climate are shown in Figure 1.

\section{Low cut}

The rates of parasite recovery from the herbage were very low in all weeks. The quantity of recovered L3 was similar for all herbage species in all weeks, except in the first one, when a larger number of $\mathrm{L} 3$ was recovered from Aruana herbage, compared to Coast-cross herbage $(\mathrm{P}<0.05$, Figure 2$)$. Until the $8^{\text {th }}$ week, L3 were recovered from all herbage species. In the $12^{\text {th }}$ week, only Brachiaria and Coast-cross showed recovery, although at small amounts. In the $16^{\text {th }}$ week, recovery was only possible from Coast-cross herbage, at minimal quantities. From the $8^{\text {th }}$ week, L3 were not recovered from Aruana herbage. The maximal development rates for free-living stages of the parasite in the feces occurred in the $2^{\text {nd }}$ week: $3.1 \%$ for Brachiaria, 3.69\% for Aruana, and 3.3\% for Coast-cross.

The mean number of L3 recovered from the feces was high in the $2^{\text {nd }}$ week for samples deposited among all herbage species: 91.5 L3 for Brachiaria, 109.2 L3 for Aruana, and 96.3 L3 for Coast-cross. In the remaining weeks, the number of recovered L3 was smaller. There was no difference between herbage species in any phase $(\mathrm{P}>0.05)$.

The largest number of recovered L3/kg DM was found for Aruana herbage $(900.80 \mathrm{~L} 3 / \mathrm{kg} \mathrm{DM})$ in the $1^{\text {st }}$ week after contamination, which is statistically different $(\mathrm{P}<0.05)$ from the value obtained for Coast-cross ( $58.9 \mathrm{~L} 3 / \mathrm{kg}$ DM). Eight weeks after plot contamination, there was an increase in the mean number of $\mathrm{L} 3$ recovered from Coast-cross herbage $(849.3 \mathrm{~L} 3 / \mathrm{Kg} \mathrm{DM}$,
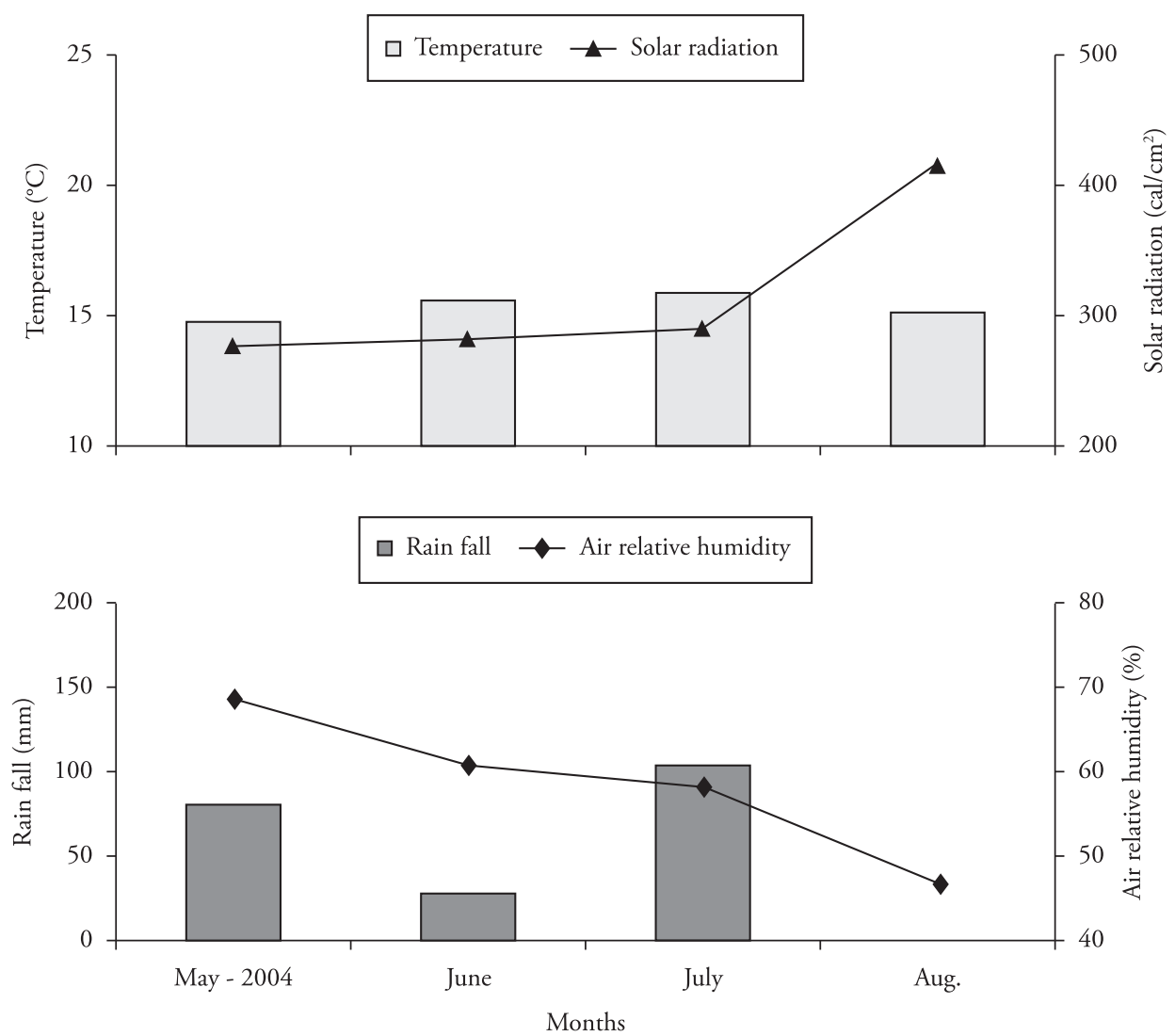

Figure 1. Monthly means of temperature $\left({ }^{\circ} \mathrm{C}\right)$, air relative humidity $(\%)$, total rainfall $(\mathrm{mm})$ and solar radiation $\left(\mathrm{cal} / \mathrm{cm}^{2}\right)$ from May to August 2004 in Botucatu, State of Sao Paulo, Brazil. 
Figure 2). In the following weeks, recovery of $\mathrm{L} 3 / \mathrm{Kg} \mathrm{DM}$ from Coast-cross herbage was minimal.

As to herbage height (Figure 2), in weeks 1, 2 and 4, Coast-cross herbage showed values significantly superior to those of Brachiaria $(\mathrm{P}<0.05)$.

Herbage weight remained similar, without significant difference ( $\mathrm{P}>0.05$ ) between herbage species, except for the $16^{\text {th }}$ week, when Coast-cross herbage (14.34 g) presented greater weight than Brachiaria (12.56) and Aruana (7.77 g, P < 0.05).

No fecal degradation over the experimental weeks was observed, and fecal pellets remained intact.

\section{High cut}

In the $2^{\text {nd }}$ and $8^{\text {th }}$ weeks, parasite development rate was greater than $1 \%$ for fecal samples deposited among all herbage species. The following results were obtained: 1.9 and $1.5 \%$ for Brachiaria, 1.1 and $2.2 \%$ for Aruana, and 1.7 and 2.4\% for Coast-cross, in the $2^{\text {nd }}$ and $8^{\text {th }}$ weeks, respectively.

L3 were recovered from herbage until the $12^{\text {th }}$ week after contamination, except from Brachiaria, where L3 were found only until the $8^{\text {th }}$ week (Figure 3). The herbage species influenced L3 recovery in the $4^{\text {th }}$ week, when the number of $\mathrm{L} 3$ recovered from Aruana herbage was superior to that recovered from Coast-cross

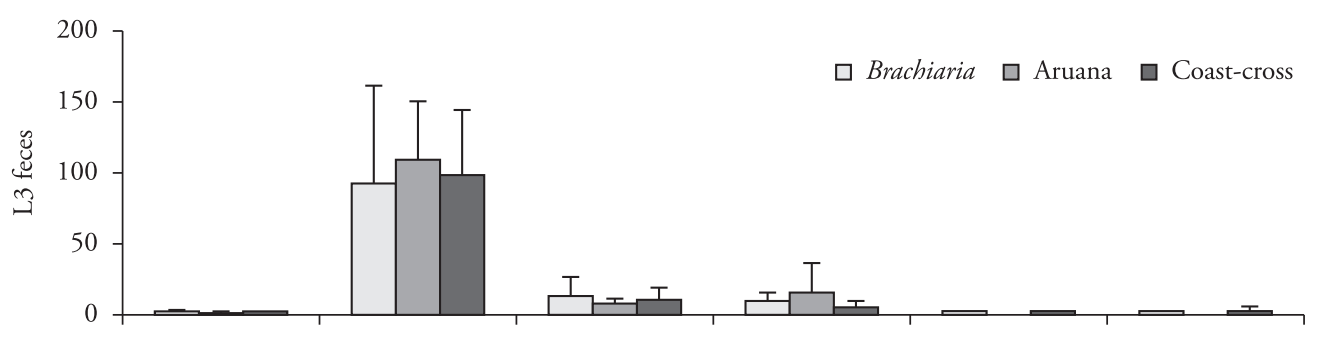

(b)
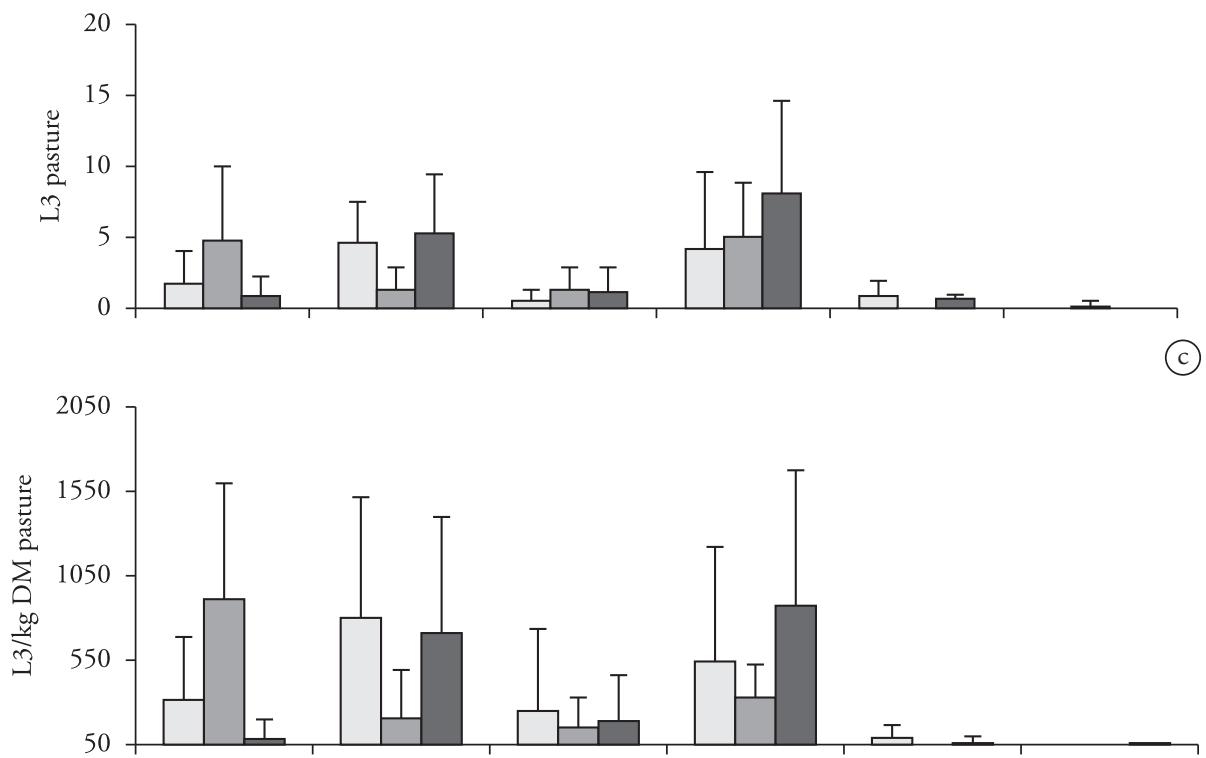

(d)

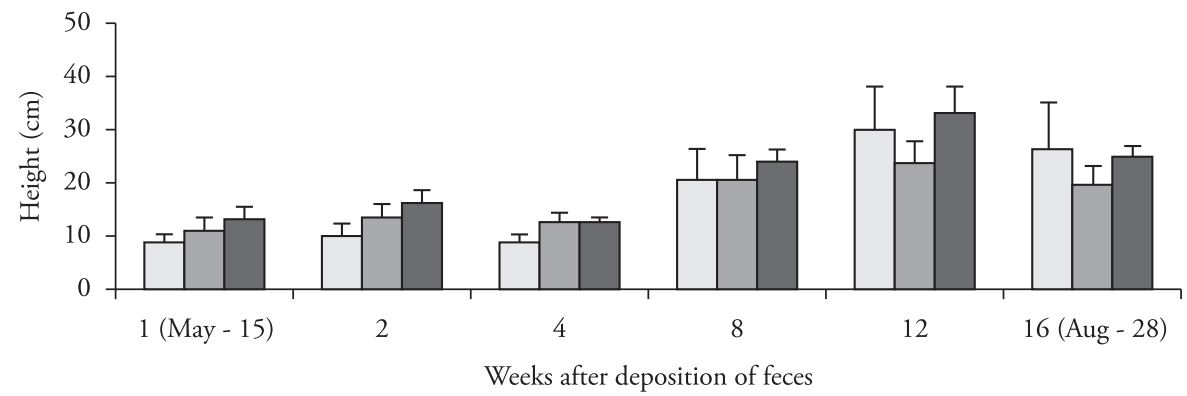

Figure 2. Mean numbers of infective larvae of Trichostrongylus colubriformis in feces (a), pasture (b) and per kilogram of herbage dry matter (L3/kg DM) (c). Mean pasture height (d) for Brachiaria, Aruana and Coast-cross over the experiment carried out in Botucatu, State of Sao Paulo, Brazil. Samples deposited among pasture with initial height of $5 \mathrm{~cm}$ (on May 07, 2004). Bars = standard deviation. 

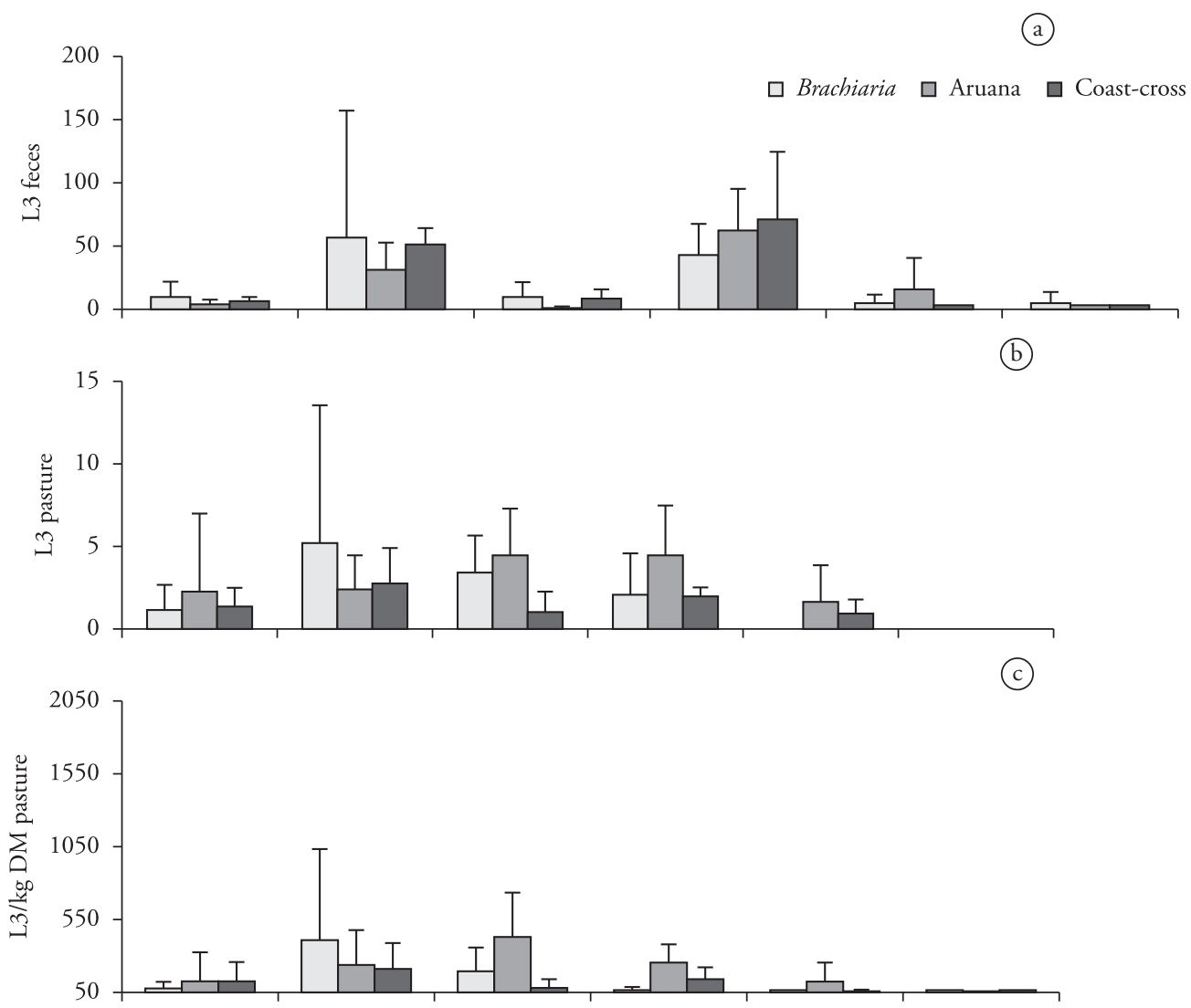

(d)

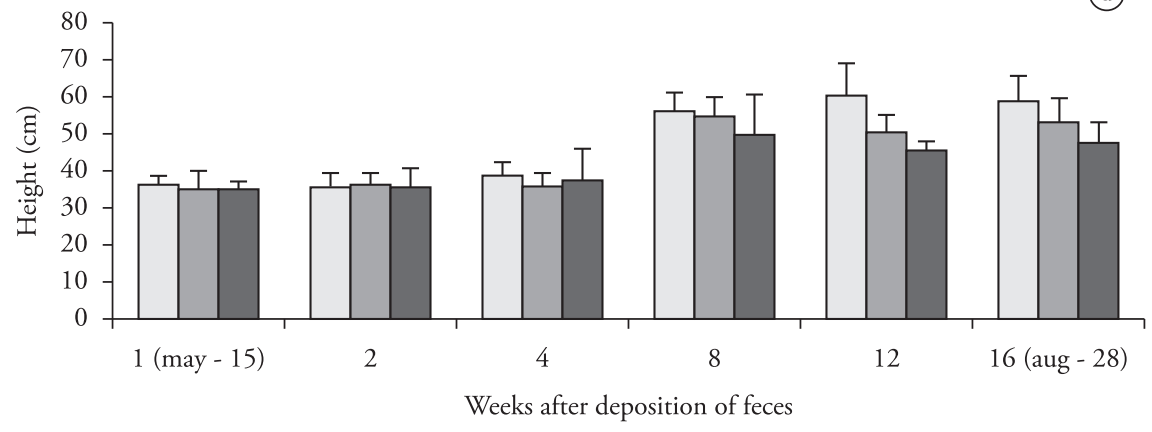

Figure 3. Mean numbers of infective larvae of Trichostrongylus colubriformis in feces (a), pasture (b) and per kilogram of herbage dry matter (L3/kg DM) (c). Mean pasture height (d) for Brachiaria, Aruana and Coast-cross over the experiment carried out in Botucatu, State of Sao Paulo, Brazil. Samples deposited among pasture with initial height of $30 \mathrm{~cm}$ (on May 07, 2004). Bars = standard deviation.

$(\mathrm{P}<0.05)$. Regarding the feces, $\mathrm{L} 3$ were recovered in all experimental weeks, with no significant difference between herbage species $(\mathrm{P}>0.05)$. The amounts of recovered feces were similar between herbage species $(\mathrm{P}>0.05)$.

Considering the quantities of L3/kg DM, Aruana herbage showed higher concentration of larvae than the remaining herbage species $(\mathrm{P}<0.05)$. In the $8^{\text {th }}$ week, Brachiaria had lower concentration, compared to the remaining herbages $(\mathrm{P}<0.05)$.

The quantities of recovered feces were similar among herbage species $(\mathrm{P}>0.05)$.

In the $12^{\text {th }}$ week, Brachiaria was higher $(60.33 \mathrm{~cm})$ than Aruana and Coast-cross (50 cm and $44.67 \mathrm{~cm}$, respectively, $\mathrm{P}<0.05)$. In the $16^{\text {th }}$ week, Brachiaria was higher $(58.33 \mathrm{~cm})$ than Coast-cross $(46.83 \mathrm{~cm})(\mathrm{P}<0.05$, Figure 3$)$.
Regarding herbage weights, there was a significant difference in the $8^{\text {th }}$ week $(\mathrm{P}<0.05)$, when Brachiaria presented weight superior (43.45 g) than Aruana (20.5 g) and Coast-cross (16.74 g).

Similarly to the low pasture, fecal degradation was not observed along the experimental weeks.

\section{Comparison between low cut and high cut}

As regards the recovery of $\mathrm{L} 3$ from the feces, the high cut of Aruana and Coast-cross herbage resulted in higher values in the $1^{\text {st }}$ week. In the $12^{\text {th }}$ week, there was higher recovery of L3 from the feces deposited among high cuts of Brachiaria and Aruana. However, in the $2^{\text {nd }}$ week, recovery of $\mathrm{L} 3$ from the feces was higher for low cut than for high cut of Aruana and Coast-cross $(\mathrm{P}<0.05)$. The same occurred in the $4^{\text {th }}$ week, but only for Aruana $(\mathrm{P}<0.05)$. 
L3 recovery from high cut of Brachiaria and Aruana was greater in the $4^{\text {th }}$ week, compared to low cut $(\mathrm{P}<0.05)$. As to the concentration of $\mathrm{L} 3 / \mathrm{kg} / \mathrm{DM}$, there was difference only in the $1^{\text {st }}$ week, when recovery was higher for Aruana low cut $(\mathrm{P}<0.05)$.

\section{Discussion}

In general, in the present study, larvae were recovered from both herbage and feces until the $16^{\text {th }}$ week. Development rates greater than $1 \%$ were recorded. The prolonged persistence of these larvae in the environment was probably due to the warmer temperatures. These results corroborate those of Amarante et al. (1996), who studied the contamination of paddocks subjected to continuous grazing by cattle and sheep in the same region of the present study and found a larger number of Trichostrongylus spp. L3 in May, September and October. After two weeks of pasture contamination, Carneiro and Amarante (2008) recovered only 2\% $H$. contortus $\mathrm{L} 3$ from feces when the latter were deposited among high cuts of Aruana herbage in the autumn. Silva et al. (2008) contaminated pastures of $B$. decumbens with feces containing Haemonchus contortus $\mathrm{L} 3$ and verified low recovery of $\mathrm{L} 3$ from both feces and herbage: $0.41 \%$ and $0.42 \%$, respectively, in the autumn.

The number of L3 recovered from the pastures was not influenced by the height of plants, except for Brachiaria and Aruana herbage in the fourth week, when the high cut led to higher L3 recovery compared to the low cut. Carneiro and Amarante (2008), in a study carried out in the same site of the present experiment, also observed higher recovery of $H$. contortus $\mathrm{L} 3$ from $30 \mathrm{~cm}$ high Aruana herbage at the moment of contamination. Rocha et al. (2008), however, did not find influence of the herbage height on the recovery of T. colubriformis $\mathrm{L} 3$ in the summer. Such results indicate that the variation in the climate conditions may change the migration of gastrointestinal nematodes. This was shown by Silva et al. (2008), who observed that the different temperatures and air relative humidity influenced the migration of $H$. contortus L3 from the feces to the pasture. Bassetto et al. (2009) found mean contamination of $8.59 \mathrm{~L} 3 / \mathrm{Kg}$ DM by Haemonchus spp. and 3.17 L3/Kg DM by Trichostrongylus spp. in a continuous grazing area in the same months of the present study.

Concerning the concentrations of larvae (L3/ $\mathrm{kg} \mathrm{DM})$ recovered from all three herbage species; there was higher concentration in low pastures. In high pastures, there was a dilution in the quantities of larvae. Dilution in the concentration of L3 leads to a decrease in the ingestion of larvae by animals, consequently reducing their exposure to parasites.

The concentrations of larvae (L3/ kg DM) were higher in May, two weeks after the deposition of feces. A total (sum of all weeks) of $5924.49 \mathrm{~L} 3 / \mathrm{kg}$ DM for low cut and $2496.54 \mathrm{~L} 3 / \mathrm{kg}$ DM for high cut were recorded. Carneiro et al. (1990) also found an increase in contamination in October, April and May. Similar results were obtained by Almeida et al. (2005) in 'Baixada Fluminense', Rio de Janeiro. In the dry period (May to October), L3 survival time was of 15 weeks in the pasture contaminated with fecal samples from sheep and goats, whereas for the bovine samples L3 recovery occurred until 21 weeks after herbage contamination, reaching its peak in the third week (ALMEIDA et al., 2005).
L3 recovery extended during the autumn and until the beginning of the winter, showing that the larvae are capable of surviving repeated desiccation and rehydration cycles without suffering deleterious effects. The anhydrobiosis phenomenon is the temporary suspension of vital activities, which allow a nematode to bear a long dehydration, prolonging thus its survival in the environment due to its lipid reserves. According to Lettini and Sukhdeo (2006), nematodes from ruminants are capable of surviving seven desiccation and rehydration cycles, waiting for suitable environmental conditions to infect the host. Amarante et al. (1996) also recorded expressive numbers of $\mathrm{L} 3$ in the pasture in the dry months.

As a rule, the highest amount of $\mathrm{L} 3$ was obtained two months after the deposition of feces. Four months after the deposition of feces, L3 were still recovered, but at minimal quantities. In the dry regions of Africa, pastures can be considered safe three months after contamination (NDAMUKONG; NGONE, 1996). In Niger, pastures for sheep and goats can be considered free of contamination in the dry period (CHIEJINA et al., 1989). Similarly, in the semi-arid region of northeastern Brazil, the transmission of parasites is almost nil in dry periods (CHARLES, 1989).

Fecal pellets were kept intact over the 112 days of the study, especially when the herbage was $30 \mathrm{~cm}$ high, determining an important source of $\mathrm{L} 3$ in the pasture. Fecal pellets act as reservoirs of infective larvae, especially during dry periods (CARRATORE, 2004; ROCHA, 2006). However, in rainy periods, the degradation of feces is higher (ROCHA et al., 2008). Rocha et al. (2008) recovered, on average, only $20 \%, 31.5 \%$ and $36.6 \%$ from the feces deposited among Brachiaria, Aruana and Coast-cross herbage, respectively, in the last sampling (16 weeks after deposition of feces in the summer).

The climate, the relative proportions of susceptible and resistant hosts in the herd, the history of pasture use and the soil structure also influence the environmental contamination.

The herbage species can influence the development and survival of gastrointestinal nematode larvae (MARLEY et al., 2006a, b). In general, Aruana herbage favored the highest L3 concentrations compared to the remaining herbage species, which was also observed for H. contortus L3 by Carneiro and Amarante (2008). Brachiaria and Coast-cross were the densest herbage species, which probably led to an effect of dilution of L3 with lower availability of infective larvae.

During the autumn, in the study site, T. colubriformis is resistant to the environmental conditions and the development and survival of the parasite free-living stages was not affected by the different herbage species.

\section{Acknowledgements}

The authors are grateful to CAPES, FAPESP and CNPq for the scholarships awarded to Raquel A. da Rocha, Patrizia A. Bricarello and Alessandro F. T. Amarante, respectively.

\section{References}

Almeida LR, Castro AA, Silva FJM, Fonseca AH. Desenvolvimento, sobrevivência e distribuição de larvas infectantes de nematóides gastrintestinais de ruminantes, na estação seca da Baixada Fluminense, RJ. Rev Bras Parasitol Vet 2005; 14(3): 89-94. PMid:16229751. 
Amarante AFT, Barbosa MA, Oliveira MAG, Carmello MJ, Padovani CR. Efeito da administraçáo de oxfendazol, ivermectina e levamisol sobre os exames coproparasitológicos de ovinos. Braz J Vet Res Anim Sci 1992; 29(1): 31-38.

Amarante AFT, Padovani CR, Barbosa MA. Contaminação da pastagem por larvas infectantes de nematódeos gastrintestinais parasitas de bovinos e ovinos em Botucatu-SP. Rev Bras Parasitol Vet 1996; 5(2): 65-73.

Bassetto CC, Silva BF, Fernandes S, Amarante AFT. Contaminação da pastagem com larvas infectantes de nematoides após o pastejo de ovelhas resistentes ou susceptíveis à verminose. Rev Bras Parasitol Vet 2009; 18(4): 63-68. PMid:20040212. http://dx.doi.org/10.4322/ rbpv.01804012

Bartley DJ, Jackson F, Jackson E, Sargison N. Characterisation of two triple resistant field isolates of Teladorsagia from Scottish lowland sheep farms. Vet Parasitol 2004; 123(3-4): 189-199. PMid:15325045. http:// dx.doi.org/10.1016/j.vetpar.2004.06.018

Bartley DJ, Donnan AA, Jackson E, Sargison N, Mithcell GBB, Jackson F. A small scale survey of ivermectin resistance in sheep nematodes using faecal egg count reduction test on samples collected from Scottish sheep. Vet Parasitol 2006; 137(1-2): 112-118. PMid:16426761. http://dx.doi. org/10.1016/j.vetpar.2005.12.014

Carneiro JR, Linhares GC, Calil F, Rodrigues N, Campos DMB. Dinâmica das parasitoses gastrintestinais de bovinos em pastagens de braquiária e andropogon. Arq Bras Med Vet Zootec 1990; 42(5): 371-378.

Carneiro RD, Amarante AFT. Seasonal effect of three pasture plants species on the free-living stages of Haemonchus contortus. Arq Bras Med Vet Zootec 2008; 60(4): 864-872. http://dx.doi.org/10.1590/ S0102-09352008000400014

Carratore RRD. Recuperação de larvas infectantes de Haemonchus contortus em três espécies de gramineas [Tese]. Botucatu: Universidade Estadual Paulista; 2004

Carvalho EB, Oliveira MAG, Domingues PF. Base para criação de ovinos no Estado de São Paulo. São Manuel: ASPACO; 2004. 92 p.

Charles TP. Seasonal prevalence of gastrointestinal nematodes of goats in Pernambuco State, Brazil. Vet Parasitol 1989; 30(4): 335-343. http:// dx.doi.org/10.1016/0304-4017(89)90103-9

Chiejina SN, Fakae BB, Eze PI. Development and survival of free-living stages of gastrointestinal nematodes of sheep and goats on pasture in the Nigerian derived savanna. Vet Res Commun 1989; 13(2): 103-112. PMid:2773307. http://dx.doi.org/10.1007/BF00346720

Echevarria FAM, Borba MFS, Pinheiro AC, Waller PJ, Hansen JW. The prevalence of anthelmintic resistance in nematode parasites of sheep in
Southern Latin America: Brasil. Vet Parasitol 1996; 62(3-4): 199-206. http://dx.doi.org/10.1016/0304-4017(95)00906-X

Lettini SE, Sukhdeo MVK. Anhydrobiosis increases survival of trichostrongyle nematodes. J Parasitol 2006; 92(5): 1002-1009. PMid:17152941. http://dx.doi.org/10.1645/GE-784R.1

Marley CL, Fraser MD, Roberts JE, Fychan R, Jones R. Effects of legume forages on ovine gastrointestinal parasite development, migration and survival. Vet Parasitol 2006a; 138(3-4): 308-317. PMid:16516388. http:// dx.doi.org/10.1016/j.vetpar.2006.02.001

Marley CL, Cook R, Barrett J, Keatinge R, Lampkin NH. The effects of birdsfoot trefoil (Lotus corniculatus) and chicory (Cichorium intybus) when compared with perennial ryegrass (Lolium perenne) on ovine gastrointestinal parasite development, survival and migration. Vet Parasitol 2006b; 138(3-4): 280-290. PMid:16495015. http://dx.doi. org/10.1016/j.vetpar.2006.01.029

Ndamukong KJN, Ngone MM. Development and survival of Haemonchus contortus and Trichostrongylus sp. on pasture in Cameroon. Trop Anim Health Prod 1996; 28(3): 193-198. PMid:8888523. http:// dx.doi.org/10.1007/BF02240933

Niezen JH, Waghorn GC, Charleston WAG. Establishment and fecundity of Ostertagia circumcincta and Trichostrongylus colubriformis in lambs fed lotus (Lotus pedunculatus) or perennial ryegrass (Lolium perenne). Vet Parasitol 1998; 78(1): 13-21. http://dx.doi.org/10.1016/ S0304-4017(98)00121-6

Rocha RA, Bricarello PA, Rocha GP, Amarante AFT. Recuperação de larvas de Trichostrongylus colubriformis em diferentes estratos de Brachiaria decumbens e Panicum maximum. Rev Bras Parasitol Vet 2007; 16(2): 77-82. PMid:17706008.

Rocha RA, Rocha GP, Bricarello PA, Amarante AFT. Recuperação de larvas infectantes de Trichostrongylus colubriformis em três espécies de gramíneas contaminadas no verão. Rev Bras Parasitol Vet 2008; 17(4): 227-234. PMid:19265583.

Rocha RA. Sobrevivência e migração vertical de larvas infectantes de Trichostrongylus colubriformis em gramineas, nas diferentes estaçôes do ano [Tese]. Botucatu: Universidade Estadual Paulista; 2006.

Silva BF, Amarante MRV, Kadri SM, Carrijo-Mauad JR, Amarante AFT. Vertical migration of Haemonchus contortus third stage larvae on Brachiaria decumbens grass. Vet Parasitol 2008; 158(1-2): 85-92. PMid:18824304. http://dx.doi.org/10.1016/j.vetpar.2008.08.009

Waller PJ. Anthelmintic resistance. Vet Parasitol 1997; 72(3-4): 391-412. http://dx.doi.org/10.1016/S0304-4017(97)00107-6 